\title{
STUDI KUALITATIF: PENANGANAN AWAL PREEKLAMPSIA BERAT OLEH BIDAN
}

\author{
Hariyanti ${ }^{1}$, Mumun Munigar ${ }^{1}$, Elina Lukman ${ }^{1}$ \\ ${ }^{1}$ Jurusan Kebidanan, Politeknik Kesehatan Kemenkes Jakarta I, Indonesia
}

\begin{tabular}{l}
\hline Info Artikel \\
\hline Genesis Naskah: \\
Submissions: $29-10-2020$ \\
Revised: $7-11-2020$ \\
Accepted: $10-11-2020$
\end{tabular}

\section{Kata Kunci:}

Bidan, $\mathrm{MgSO}_{4}$,

Penanganan awal,

Preeklampsia.

\author{
Abstrak
}

Preeklampsia penyebab kematian ibu nomor satu di Indonesia. Preeklampsia ditangani dengan menegakkan diagnosis dini dan mencegah agar tidak berlanjut menjadi eklampsia, dengan memberikan magnesium sulfat $\left(\mathrm{MgSO}_{4}\right)$ secara dini. Hasil penelitian di RSUP Fatmawati menunjukkan bahwa 96\% tenaga kesehatan yang melaksanakan praktek secara mandiri tidak memberikan $\mathrm{MgSO}_{4}$ pada pasien preeklampsia berat sebelum merujuk ke RS, dan 93,3\% puskesmas juga tidak memberikan $\mathrm{MgSO}_{4}$, sehingga pada penelitian ini perlu dikaji secara mendalam tentang faktor pendorong dan penghambat penanganan awal preeklampsia berat oleh tenaga kesehatan terutama bidan sebagai garda terdepan pelayanan kesehatan ibu dan anak. Metode penelitian yang digunakan adalah kualitatif dengan pendekatan Rapid Assessment Procedures (RAP). Subyek penelitian ini adalah bidan yang bekerja di puskesmas dan bidan yang melakukan praktik mandiri. Hasil penelitian diperoleh informasi bahwa bidan tidak memberikan $\mathrm{MgSO}_{4}$ pada penanganan awal preeklampsia disebabkan rasa percaya diri yang rendah terhadap pelaksanaan penanganan awal preeklampsia berat, faktor kepraktisan, tidak tersedia obat akibat kurang diperhatikannya tanggal kadaluwarsa obat, dan tidak tersedianya laboratorium. Pada hasil penelitian ini juga terungkap faktor lain yang berkontribusi terhadap pelaksanaan penanganan awal preeklampsia berat yaitu kurangnya sosialisasi, ketersediaan SOP tidak jelas, dan faktor pengalaman. Kesimpulan penelitian ini adalah perlu peningkatan keyakinan dan integritas yang tinggi dari seorang bidan dalam menjalankan kewajibannya sebagai pemberi pelayanan kebidanan, sehingga saran yang dapat diberikan adalah agar Dinas Kesehatan bersama profesi memfasilitasi pelatihan untuk bidan dan melakukan supervisi pada pelayanan kebidanan.

\section{QUALITATIVE STUDY: MIDWIVE'S EARLY MANAGEMENT OF SEVERE PREECLAMPSIA}

Keywords:
Midwife, $\mathrm{MgSO}_{4}$, Early
treatment, Preeclampsia.

\begin{abstract}
Preeclampsia is one of number cause of maternal death in Indonesia, was treated by establishing an early diagnosis and preventing progressing eclampsia, with early giving magnesium sulfate $\left(\mathrm{MgSO}_{4}\right)$. The results of research at Fatmawati Hospital show $96 \%$ of health workers who practice independently do not provide $\mathrm{MgSO}_{4}$ to severe preeclamptic patients before referring to the hospital, and $93.3 \%$ of public health center also do not provide $\mathrm{MgSO}_{4}$, in this study need to study in depth about the driving and inhibiting factors of early treatment of severe preeclampsia by health personnel, especially midwives as the front line of maternal and child health services. The research method used was qualitative with the Rapid Assessment Procedures (RAP) approach. The subjects this study were midwives who worked in health centers and midwives who practiced independently. The results obtained information midwives did not provide $\mathrm{MgSO}_{4}$ in the initial treatment of preeclampsia due to low self-esteem in the implementation of the initial treatment of severe preeclampsia, practical factors, absence of drugs, and unavailability of laboratories. The results of this study also reveal other factors that contribute to the implementation of the initial treatment of severe preeclampsia, namely lack of socialization, unclear SOP availability, and experience factors. The conclusion of study is necessary to increase the
\end{abstract}


Hariyanti/JMSWH, Volume1, Nomor 1 tahun 2020: 8-15

confidence and high integrity of a midwife in carrying out her obligations as a provider of midwifery services, the suggestion that can be given is that the Health Office together with the profession facilitate training for midwives and supervise midwifery services.

Korespondensi Penulis:

Hariyanti

Jl. Wijaya Kusuma Raya No.47-48, Cilandak Jakarta Selatan

Email: yantihariri80@gmail.com 


\section{PENDAHULUAN}

Angka Kematian Ibu (AKI) di Indonesia mencapai 305 kematian per 100000 kelahiran hidup (BPS, 2016). Penyebab kematian ibu masih didominasi oleh tiga penyebab utama kematian yaitu perdarahan, hipertensi dalam kehamilan (HDK), dan infeksi. Namun proporsinya telah berubah, yaitu perdarahan dan infeksi cenderung mengalami penurunan sedangkan HDK proporsinya semakin meningkat. Lebih dari 25\% kematian ibu di Indonesia pada tahun 2013 disebabkan oleh HDK (Kemenkes RI, 2013). Kematian ibu di kota Depok pada tahun 2014 rasio kematian ibu sebanyak 17/46.679 dan tahun 2015 sebanyak 14/40.186. Penyebab kematian ibu di kota depok sekitar 23\% disebabkan oleh preeclampsia (BPS Jawa Barat, 2015; Dinas Kesehatan Kota Depok, 2013).

Pre eklampsia ditangani dengan menegakkan diagnosis dini dan mencegah agar tidak berlanjut menjadi eklampsia (Manuaba, 2007). Untuk itu dibutuhkan penatalaksanaan preeklampsia yang tepat. Dalam suatu studi multisenter, multinasional untuk membandingkan berbagai cara pengobatan, telah dibuktikan bahwa magnesium sulfat $\left(\mathrm{MgSO}_{4}\right)$ merupakan obat yang paling efektif untuk mengatasi kejang pada eklampsia dibandingkan dengan obat lainnya. Selain itu juga obat ini mudah digunakan di Negara berkembang, karena tidak mahal dan tidak memerlukan teknologi tinggi dalam penerapannya. Untuk itu magnesium sulfat direkomendasikan menjadi obat terpilih dalam pengobatan eklampsia (POGI, 2016).

Hasil penelitian yang dilakukan oleh Hariyanti (2011) di RS Fatmawati diperoleh hasil hanya $15 \%$ ibu dengan preeklampsia berat mendapatkan $\mathrm{MgSO}_{4}$ sebelum dirujuk ke RS. Dari penelitian ini juga diperoleh informasi bahwa $96 \%$ tenaga kesehatan yang melaksanakan praktek secara mandiri tidak memberikan $\mathrm{MgSO}_{4}$ pada pasien preeklampsia berat sebelum merujuk ke RS, sedangkan puskesmas juga sebesar 93,3\% tidak memberikan $\mathrm{MgSO}_{4}$ pada pasien preeklampsia berat sebelum merujuk ke RS dan 53,3\% RS tipe $\mathrm{D}$ dan $\mathrm{C}$ tidak memberikan $\mathrm{MgSO}_{4}$ pada pasien preeklampsia berat sebelum merujuk ke RS. Data tersebut cukup ironis, karena hal ini menggambarkan tenaga kesehatan di fasilitas kesehatan tidak mampu melakukan penanganan kegawatdaruratan secara tepat yang dapat mengakibatkan pasien jatuh pada fase yang lebih parah yaitu terjadinya eklamsia pada kehamilan, persalinan dan masa nifas, dan lebih jauh lagi berdampak pada kematian ibu dan bayinya. Sehingga penelitian ini bertujuan untuk mengetahui informasi mendalam tentang peran bidan dalam melaksanakan penanganan awal preeklampsia berat.

\section{METODE}

Metode Penelitian yang digunakan adalah kualitatif dengan pendekatan Rapid Assessment Procedures (RAP). Subyek penelitian ini adalah bidan yang melaksanakan praktek secara mandiri di wilayah kerja di Puskesmas kota Depok dan bidan yang bekerja di Puskesmas tersebut. Sampel diambil secara purposive sampling. Informan kunci pada penelitian ini adalah Bidan Koordinator. Besar sampel pada penelitian ini sampai dengan saturasi berjumlah 6 partisipan. Teknik pengumpulan data pada penelitian ini adalah dengan melakukan wawancara mendalam untuk mengetahui sebab mendasar, dan juga melakukan studi dokumentasi dengan melihat catatan rekamedis pasien preeklampsia berat yang pernah ditanganinya. Pengumpulan data dilakukan pada bulan Oktober-November 2016. Setelah data terkumpul secara lengkap selanjutnya melakukan analisis data dengan cara analisis konten atau isi dengan cara mengidentifikasi katagori sebelum mencarinya dalam data (Martha \& Kresno, 2016).

\section{HASIL}

Karakterisrik partisipan diperoleh umur bidan berkisar antara 26 tahun sampai 39 tahun. Responden sebagian besar memiliki pendidikan D4 Kebidanan. Karakteristik pekerjaan terdiri dari tiga katagori yaitu Bidan Koordinator (BidKor), bidan pelaksanan dan Bidan Praktek Mandiri (BPM). Hasil analisis sesuai dengan katagori yang ditentukan adalah sebagai berikut:

\section{Pengetahuan}

Pada umumnya pengetahuan bidan tentang penanganan awal preeklampsia berat adalah baik. Hampir seluruhnya mereka menjelaskan secara rinci prosedur penanganan awal preeklampsia berat. Seperti yang disampaikan oleh salah satu Bidan Praktek Mandiri adalah sebagai berikut: 
"Dosis awal memberikan 4 gram $\mathrm{MgSO}_{4} 40 \%$ ehh.. 10 cc ditambah aquabides 10 cc diberikan per IV dalam 5 menit, dosis pemeliharaan 6 gram $\mathrm{MgSO}_{4}$ 40\% (15 cc) dalam $500 \mathrm{cc} R \mathrm{RL}$ dengan kecepatan 20 tpm, kemudian rujuk pasien ke RS" (Informan 1)

Dari informan lainnya didapatkan prosedur tindakan penting dalam penanganan awal preeklampsia berat, yaitu :

"Berikan $\mathrm{MgSO}_{4}$ dan pasang kateter itu wajib sebelum dirujuk" (Informan 4)

Hasil wawancara tentang pengetahuan, informan menyatakan bahwa pengetahuan tidak mempengaruhi petugas dalam melaksanakan penanganan awal preeklampsia berat, seperti dalam pernyataan sebagai berikut:

"Tau ilmunya kalo PEB itu dikasih MgSO4, tapi tingkat keberanian dan ke $P D$ anyya kurang..Bidan dimagangkan di RSUD Depok, sudah ada protap sudah dua tahun ini. Sebenarnya SOP yang jelas terus skil yang apa ya.. memadai sama tingkat Ke PD an kali, sebenarnya kalo pengetahuan mah sebenarnya di D3 juga kalo MgSO4 di buku pink juga ada kan..." (Informan 2)

Namun sebagian besar informan menyatakan pengetahuan sangat mendukung pelaksanaan penanganan preeklampsia secara tepat, misalnya seperti yang disampaikan oleh salah satu informan sebagai berikut:

"Pendukungnya biasanya pengetahuan kali ya bu... pengetahuan sebelumnya kayak yang sudah pelatihan di PONED yang biasanya bikin bidan-bidan PD nih bu.." (informan 6)

\section{Sikap}

Sikap bidan dalam menghadapi klien yang datang dengan preeklampsia berat seluruhnya menunjukkan sikap yang positif yang bertujuan untuk menyelamatkan nyawa pasien, yaitu melakukan pengkajian, menegakan diagnose, melakukan penanganan awal preeklampsia baik pada kondisi hamil ataupun dalam tahap persalinan, dan selanjutnya melakukan rujukan ke RS. Seperti yang dikemukan oleh beberapa informan sebagai berikut :

"mengkaji riwayat kehamilan, melakukan pemeriksaan, menegakkan diagnose, melakukan penanganan awal, rujuk pasien ke $R S$ "(Informan 1)
"Inpartu, kita..stabilisasi dengan pasang infus, berikan MgSO4 dan pasang kateter terus dirujuk"(Informan 3)

"Inpartu dikasih nipe, MgSO4 dirujuk bu.." (Informan 6)

\section{Keterampilan}

Keterampilan mempunyai peran besar terhadap pelaksanaan penanganan awal preeklampsia. Sebagian besar informan menyatakan bahwa keterampilan sangat mendukung terhadap pelaksanaan penanganan awal preeklampsia berat. Bahkan untuk meningkatkan keterampilan bidan, Dinas Kesehatan Kota Depok memberikan kesempatan kepada bidan-bidan yang bertugas di Puskesmas untuk melakukan magang di RS atau memberikan pelatihan PONED. Hal ini seperti disampaikan oleh salah satu informan sebagai berikut:

“..Bidan dimagangkan di RSUD Depok, sudah ada protap sudah dua tahun ini. Sebenarnya SOP yang jelas terus skil yang apa ya.. memadai sama tingkat $\mathrm{Ke} P D$ an kali.." (Informan 2)

\section{Keyakinan}

Tingkat keyakinan informan dalam melaksanakan penanganan awal preeklampsia berat digambarkan dari rasa takut dan percaya diri bidan dalam melakukan penanganan awal preeklampsia berat. Seperti beberapa pernyataan informan berikut ini :

"Ehh.. takut, takut karena dia ragu-ragu untuk ngasihnya, takut untuk memberikannya, ehh mungkin karena kasus jarang terjadi, jarang melakukan tindakannya, jadi takut.. untuk ngerjainya itu, jarang kurang terlatih" (Informan 3)

“...terus tingkat ke PD an misalnya $4 \mathrm{gr}$ itu seperti apa ya, ah dari pada salah mending aja ke RS..." (Informan 2)

Dari hasil wawancara didapatkan sebagian besar bidan takut dan tidak percaya diri dalam melakukan penanganan awal preeklampsia berat dengan memberikan $\mathrm{MgSO} 4$ sebelum dirujuk ke RS.

\section{Nilai Etika Profesi}


Nilai etika profesi pada penanganan awal preeklampsia berat ini digambarkan pada beberapa aspek yaitu pengetahuan bidan tentang kewenangan dalam penanganan awal preeklampsia berat, sikap dan prilaku bidan dalam pelaksanaan awal preeklampsia. Kewenangan bidan dalam melakukan penanganan awal preeklampsia berat seluruh informan menyatakan bahwa penanganan awal preeklampsia berat merupakan wewenang bidan yang harus dilaksanakan. Hal ini misalnya tergambar pada jawaban informan sebagai berikut:

"kewenangan bidan dalam penatalaksanaan kasus PEB terbatas pada penanganan awal saja. Setelah dilakukan penanganan awal pasien dirujuk ke RS" (Informan 1)

Bahkan salah satu informan mengilustrasikan sampai ke ranah hukum, berikut pernyataan informan tersebut:

"Boleh justru gini bu, misalkan ada dua kejadian pasien PEB yang dirujuk tanpa $\mathrm{MgSO}_{4}$ meninggal, yang satu dari bidan diberikan $\mathrm{MgSO}_{4}$ dirujuk meninggal, kalo secara hukum pidana yang salah yang akan dikenakan pidana itu bidan yang merujuk tanpa $\mathrm{MgSO}_{4}$ meninggal"(Informan 2)

Hal lain juga terungkap perilaku bidan yang tidak sesuai dengan wewenang bidan yaitu faktor kepraktisan tanpa memandang keselamatan nyawa pasien. Hal ini tertera pada jawaban informan sebagai berikut:

“...trus ada juga faktor ribet harus pasang infus udah lah rujuk lepas aja..” (Informan 2)

\section{Ketersediaan obat}

Hasil wawancara mendalam diperoleh seluruh bidan baik yang bekerja di Puskesmas ataupun Bidan Praktek Mandiri (BPM) menyediakan obat dan alat penanganan awal preeklampsia berat yang terdiri dari $\mathrm{MgSO} 4$ dan anti dotumnya, infus set, kateter, spuit, akuabidestilata dan alat kesehatan lainnya. Hal ini tergambar dari jawaban informan sebagai berikut :

"Di BPM, tersedia MgSO4 40\%, aquabidest, spuit $20 \mathrm{cc}$, 10cc, cairan infus dan set infus lengkap" (Informan 1)
Hasil wawancara mendalam juga didapatkan informasi bahwa untuk tanggal kadaluwarsa obat kurang diperhatikan, terutama di BPM. Seperti yang dinyatakan oleh informan sebagai berikut :

"di rumah ada bu, karena sering gak terpake jadi ya.. gitu” (Informan 3)

"Ketersediaan obat, bisa saja stok obat dari 2015 misalkan, karena nggak pernah kejadian $P E B$ anteng-anteng aja ED nya gak diperhatikan" (Informan 2)

\section{Kolaborasi}

Kolaborasi sangat penting dilaksanakan dalam penanganan awal preeklampsia berat. Fasilitas kesehatan seperti Puskesmas mampu PONED sudah memiliki tim untuk penanganan kegawatdaruratan. Hal ini peperti yang disampaikan oleh informan sebagai berikut:

"Kita punya dokter konsulen dari RS HGA, bila ditemukan pasien PEB kita konsulkan ke $d r$ PONED nya, nanti dari dokter yang akan merujuk ke RS"' (Informan 4)

Demikian juga BPM sudah melasanakan kolaborasi dengan dokter penanggung jawabnya, seperti disampaikan dalam pernyataan berikut :

"Kita cek protein urin, teruskan dikonsulkan ke dokter umum, terus dirujuk, konsulen juga ada" (Informan 5)

Dalam penelitian ini juga diperoleh sejumlah informasi disamping variabel-variabel yang diteliti di atas. Penyebab bidan tidak melakukan penanganan preeklampsia secara benar antara lain sosialisasi yang kurang, protap atau SOP yang belum jelas, tidak tersedianya laboratorium dan pengalaman bidan. Hal ini seperti disampaikan oleh beberapa informan sebagai berikut:

“..Mungkin dulu ya karena sosialisasi untuk Mg juga belum lengkap...” (Informan 5 dan 6)

“..sudah ada protap sudah dua tahun ini. Sebenarnya SOP yang jelas (Informan 2 dan 4)" 
"...faktor ketersediaan laboratorium protein urin menggunakan stik BPM jarang punya..." (Informan 2)

“...intinya jam terbang kita lah untuk masangmasangnya, pengalaman lah yang paling utama dan ilmunya juga ada..." (Informan 5)

\section{PEMBAHASAN}

\section{Pengetahuan}

Hasil penelitian didapatkan seluruh informan memiliki pengetahuan yang baik tentang penanganan awal preeklampsia berat. Dan sebagian besar informan juga menyatakan bahwa pengetahuan mendukung perilaku penanagan awal preeklampsia berat. Hasil penelitian ini sejalan dengan hasil penelitian Rahmawati (2015) yang menyatakan bahwa ada hubungan antara pengetahuan dengan praktik bidan dalam pemberian $\mathrm{MgSO}_{4}$ pra rujukan pada preeklampsia. Demikian juga hasil penelitian Serudji, dkk (2014) yang menyatakan bahwa faktor yang berhubungan dengan perilaku bidan, salah satunya adalah pengetahuan.

Pengetahuan merupakan domain penting dan faktor awal seseorang untuk berperilaku. Selain itu, perilaku yang didasari oleh pengetahuan akan lebih melekat dan tahan lama dibandingkan perilaku yang tidak didasari oleh pengetahuan. Pemberian informasi melalui pendidikan, pelatihan atau seminar tersebut akan meningkatkan pengetahuan seseorang dan selanjutnya akan menimbulkan kesadaran untuk berperilaku sesuai dengan pengetahuan yang dimilikinya. Tanpa pengetahuan, seseorang tidak mempunyai dasar untuk mengambil keputusan dan menentukan tindakan terhadap masalah yang dihadapi (Notoatmodjo, 2011).

Pada penelitian ini juga didapatkan hasil bahwa bahwa pengetahuan tidak mempengaruhi petugas dalam melaksanakan penanganan awal preeklampsia berat. Hal ini menunjukkan bahwa perilaku banyak dipengaruhi oleh banyak hal, tidak hanya semata oleh pengetahuannya saja.

\section{Sikap}

Hasil penelitian menunjukkan seluruh informan memiliki sikap yang positif dalam menghadapi klien yang datang dengan preeklampsia berat. Hasil penelitian ini sejalan dengan hasil penelitian Serudji, dkk (Serudji, 2014) bahwa faktor-faktor yang berhubungan dengan perilaku bidan adalah pengetahuan, sikap, motivasi, supervisi dan ketersediaan sarana.

Sikap merupakan reaksi atau respon yang masih tertutup dari seseorang terhadap suatu stimulus atau objek, bersifat seperti evaluasi pribadi seseorang terhadap stimulus yang diterima. Sikap juga merupakan suatu kesiapan untuk bereaksi secara positif atau negatif terhadap suatu objek dengan cara tertentu. Sikap tidak dapat dilihat tetapi hanya dapat ditafsirkan terlebih dahulu dari perilaku yang tertutup (covert behavior). Menurut Allport tahun 1954 dalam Azwar S (2007), menyatakan bahwa komponen sikap ada 3 komponen, yaitu kognitif (pengetahuan, keyakinan), afektif (emosional, evaluasi) dan konatif (kecenderungan bertindak). Ketiga komponen ini bersama-sama akan membentuk sikap yang utuh (total attitude) suatu sikap belum otomatis terwujud dalam suatu perilaku terbuka (overt behaviour), karena faktor lain yang juga turut berpengaruh seperti ketersediaan sarana, dukungan atasan/organisasi profesi, atau situasi lingkungan yang tidak memungkinkan.

\section{Keterampilan}

Sebagian besar informan menyatakan bahwa keterampilan sangat mendukung terhadap pelaksanaan penanganan awal preeklampsia berat. Hal ini sejalan dengan hasil penelitian Astuti (Astuti, 2013) yang menunjukkan ada hubungan signifikan antara kemampuan dan ketrampilan dengan kinerja bidan. kemampuan dan ketrampilan memainkan peranan penting dalam perilaku dan kinerja individu (Gibson, Ivancevich, \& Donnelly, 2000). Kemampuan dan ketrampilan bisa ditingkatkan dengan pelatihan. Hal ini sejalan dengan teori yang diungkapkan oleh Gerry Dessler yang dikutip oleh Prabu (2007), yang menyatakan bahwa pelatihan memberikan pegawai baru atau yang ada sekarang mempunyai kemampuan yang mereka butuhkan untuk melaksanakan pekerjaan.

Berdasarkan teori Gibson (2000), kinerja dipengaruhi oleh kondisi individu, psikologi, dan organisasi. Kondisi individu meliputi kemampuan dan ketrampilan, latar belakang, dan demografis, sedangkan kondisi psikologis meliputi persepsi, sikap, kepribadian, belajar, dan motivasi, sedangkan untuk kondisi organisasi meliputi sumber daya, 
kepemimpinan, imbalan, dan struktur dan desain kerja.

\section{Keyakinan}

Tingkat keyakinan bidan dalam penanganan awal preeklampsia berat digambarkan melalui rasa takut dan rasa percaya diri dalam melakukan tindakan penanganan awal preeklampsia berat tersebut. Hasil penelitian didapatkan bahwa sebagian besar bidan takut dan tidak percaya diri dalam melakukan penanganan awal preeklampsia berat dengan memberikan $\mathrm{MgSO}_{4}$ sebelum dirujuk ke RS. Banyak faktor yang dapat memepengaruhi keyakinan seseorang untuk bertindak antara lain pengetahuan, pengalaman, pelatihan dan lain-lain. Menurut Notoatmodjo (2011) pengetahuan dapat membentuk keyakinan tertentu sehingga seseorang dapat berperilaku sesuai keyakinan tersebut.

\section{Nilai Etika Profesi}

Nilai merupakan suatu proses dimana seseorang dapat mengerti sistem nilai-nilai yang melekat pada dirinya sendiri. Nilai dapat terlihat dari kemampuan seseorang dalam hal ini bidan melaksanakan tugas dan tanggung jawabnya secara benar. Seorang bidan harus memiliki komitmen yang tinggi untuk memberikan asuhan kebidanan yang berkualatas berdasarkan standar perilaku yang etis dalam praktek asuhan kebidanan. Pada penelitian ini didapatkan informasi bahwa seluruh informan menyatakan penanganan awal preeklampsia berat merupakan wewenang bidan yang harus dilaksanakan. Pada penelitian ini juga terungkap perilaku bidan yang tidak sesuai dengan tugas dan tanggung jawab bidan yaitu faktor kepraktisan tanpa memandang keselamatan nyawa pasien. Dalam hal ini bidan tidak mau direpotkan dengan tindakan yang seharusnya dilaksanakan. Hal ini tidak sesuai dengan kewajiban bidan yang menyatakan bahwa Bidan wajib memberikan pelayanan asuhan kebidanan sesuai dengan standar profesi dengan menghormati hak-hak pasien (Wahyunungsih \& Heni, 2009).

\section{Ketersediaan Obat}

Hasil wawamcara mendalam diperoleh bahwa seluruh bidan baik yang bekerja di Puskesmas ataupun Bidan Praktek Mandiri (BPM) menyediakan obat dan alat penanganan awal preeklampsia berat. Namun untuk beberapa fasilitas kesehatan obat ini tidak diperhatikan tanggal kadaluwarsanya, sehingga bila dibutuhkan tetap tidak dapat digunakan. Hasil penelitian Yunita, dkk (2013) menunjukkan adanya pengaruh bersama-sama variabel pengetahuan dan sarana prasarana terhadap kinerja bidan.

Sarana merupakan salah satu faktor pendukung yang tidak boleh dilupakan dalam pelayanan. Teori Green yang dikutip dari Notoatmodjo tahun 2011, menyebutkan bahwa faktor yang mempengaruhi perilaku sehat yaitu faktor pendukung yang mencakup tersedianya fasilitas kesehatan, tersedianya prasarana fasilitas kesehatan yang memudahkan untuk mencapai perilaku kesehatan individu dalam bertindak (Notoatmodjo, 2011). Jaminan ketersediaan sarana, peralatan dan pasokan yang memadai adalah syarat untuk melaksanakan pelayanan kesehatan agar sesuai dengan standar yang telah ditetapkan. Apabila persyaratan ini tidak terpenuhi maka hal tersebut akan menimbulkan kesenjangan antara kinerja dan kualitas pelayanan. Sekompeten apapun seorang petugas kesehatan, tidak akan dapat melakukan unjuk kinerja yang memadai apabila sarana dan pasokan untuk menyelenggarakan pelayanan yang berkualitas, tidak dapat dipenuhi oleh pemilik dan pengelola fasilitas kesehatan tersebut (WHO, Kemenkes RI, IBI, \& POGI, 2013).

\section{Kolaborasi}

Kolaborasi sangat penting dilaksanakan dalam penanganan awal preeklampsia berat. Hasil penelitian menunjukan bahwa seluruh informan melakukan kolaborasi dalam penanganan awal preeklampsia berat. Hal ini seperti disampaikan oleh Wahyunungsih dan Heni (2009) bahwa salah satu kewajiban bidan adalah bidan wajib merujuk pasien dengan penyulit kepada dokter yang mempunyai kemampuan dan keahlian sesuai dengan kebutuhan pasien.

Hasil penelitian ini juga diperoleh sejumlah informasi disamping variabel-variabel yang diteliti tentang penyebab bidan tidak melakukan penanganan preeklampsia secara benar antara lain sosialisasi yang kurang, prossedur tetap (Protap) atau Standar Operasional Prosedur (SOP) yang belum jelas, tidak tersedianya laboratorium dan pengalaman bidan. Hal ini seperti telah disinggung pada pembahasan di atas yaitu terkait sarana dan prasarana, pengetahuan dan keterampilan petugas. Sosialisasi yang kurang tentang 
penanganan awal preeklampsia meangkibatkan pengetahuan petugas juga rendah, demikian juga pengalaman akan membuat seseorang menjadi lebih terampil dalam melakukan suatu tindakan, sehingga kedua faktor ini sangat penting juga untuk diperhatikan dalam hal merubah perilaku. Terkait dengan protap atau SOP dan keberadaan laboratorium marupakan hal yang harus ada dalam melaksanakan pelayanan kesehatan. SOP akan memberikan penguatan kepada perilaku tindakan yang seharusnya diberikan, sedangkan laboratorium adalah syarat mutlak untuk mendiagnosis keadaan preeklampsia.

\section{KESIMPULAN}

Penelitian ini menghasilkan informasi mendalam tentang faktor pendukung dan faktor penghambat bidan dalam melaksanakan penanganan awal preeklampsia berat dengan memberikan magnesium sulfat $\left(\mathrm{MgSO}_{4}\right)$, antara lain faktor pengetahuan, sikap, keterampilan, keyakinan, nilai-nilai, ketersediaan obat dan kolaborasi. Pada hasil penelitian ini juga terungkap faktor lain yang berkontribusi terhadap pelaksanaan penanganan awal preeklampsia berat yaitu faktor kurangnya sosialisasi, ketersediaan SOP, ketersediaan laboratorium dan faktor pengalaman.

Pada penelitian ini yang perlu digarisbawahi adalah rasa percaya diri petugas yang rendah terhadap pelaksanaan penanganan awal preeklampsia berat, penanaman nilai-nilai profesi bidan terkait dengan temuan adanya faktor tidak mau repot (faktor kepraktisan) yang dapat mengabaikan keselamatan jiwa pasien, kurang diperhatikannya tanggal kadaluwarsa obat dan ketersediaan laboratorium sederhana.

Terkait temuan pada penelitian ini, maka saran yang dapat diberikan adalah Dinas Kesehatan bersama profesi memfasilitasi pelatihan dan melakukan supervisi pada pelayanan kebidanan yang dilaksanakan di fasilitas kesehatan sesuai wilayah kerjanya.

\section{DAFTAR PUSTAKA}

Astuti, D. A. (2013). Faktor-faktor yang Berhubungan dengan Kinerja Bidan dalam Pelaksanaan Desa Siaga di Kabupaten Boyolali Factors Associated to the Work Performance of Midwives in the Implementation. 01(03).

BPS. (2016). Profil Penduduk Indonesia Hasil SUPAS.
BPS Jawa Barat. (2015). Jawa Barat Dalam Angka 2015. Bandung.

Dinas Kesehatan Kota Depok. (2013). Profil Kesehatan Depok 2013. Retrieved from http://dinkes.depok.go.id/wpcontent/uploads/narasi-profil-2013anyar1.pdf

Fitri Rahmawati, Ida Baroroh, \& Masyunah. (2015). Hubungan Tingkat Pengetahuan Dengan Praktik Bidan Dalam Pemberian Magnesium Sulfat (Mgso4) Pada Kasus Pre Eklampsia Di Kabupaten Pekalongan Tahun 2014. 107-116.

Gibson, J. L., Ivancevich, J. M., \& Donnelly, J. (2000). Organisasi Perilaku Struktur Proses (1st ed.). Jakarta: Binarupa Aksara.

Hariyanti. (2011). Pengaruh Pemberian MgSO4 Pada Pasien Preeklamsia Berat Di Tempat Pra Rujukkan Rsup Fatmawati Terhadap Kejadian Eklamsia Tahun 2009 - 2010. Health Quality, 2(3), 136-146.

Kemenkes RI. (2013). Riset Kesehatan Dasar (RISKESDAS) 2013.

Manuaba, I. B. G. (2007). Pengantar Kuliah Obstetri. Jakarta: EGC.

Martha, E., \& Kresno, S. (2016). Metodologi Penelitian Kualitatif. Jakarta: Rajawali Pers.

Notoatmodjo, S. (2011). Ilmu Perilaku Kesehatan. Jakarta: Rineka Cipta.

POGI. Pedoman Nasional Pelayanan Kedokteran Diagnosis dan Tata Laksanan Pre-Eklamsia., (2016).

Prabu MA. (2007). Manajemen Sumber Daya Manusia Perusahaan. Bandung: Rosda.

Serudji, J. (2014). Artikel Penelitian FaktorFaktor yang Berhubungan dengan Perilaku Bidan dalam Pencegahan Risiko Penularan HIV / AIDS pada Pertolongan Persalinan Normal di Kota Tanjungpinang Tahun. 3(3), 506-516.

Wahyunungsih, \& Heni. (2009). Etika Profesi Kebidanan. Yogyakarta: Fitramaya.

WHO, Kemenkes RI, IBI, \& POGI. (2013). Pedoman Pelaksanaan Pelayanan Ibu di Fasilitas Kesehatan. In Pelayanan Kesehatan Ibu Di Fasilitas Kesehatan Dasar Dan Rujukan.

Yunita, H., Kuntjoro, T., \& Purnami, C. T. (2013). Faktor-Faktor yang Mempengaruhi Kinerja Bidan Desa dalam Deteksi Dini Resiko Tinggi Ibu Hamil pada Pelayanan Antenatal di Kabupaten Bengkulu Selatan. Jurnal Manajemen Kesehatan Indonesia, 01(02). 